\title{
Long-acting muscarinic antagonist use in adults with asthma: real-life prescribing and outcomes of add-on therapy with tiotropium bromide
}

\author{
David Price ${ }^{1,2}$ \\ Alan Kaplan ${ }^{3}$ \\ Rupert Jones ${ }^{4}$ \\ Daryl Freeman ${ }^{5}$ \\ Anne Burden² \\ Shuna Gould ${ }^{2}$ \\ Julie von Ziegenweidt ${ }^{2}$ \\ Muzammil Ali² \\ Christine King ${ }^{2}$ \\ Mike Thomas ${ }^{6}$ \\ 'Academic Centre of Primary Care, \\ University of Aberdeen, Aberdeen, \\ ${ }^{2}$ Research in Real-Life, Cambridge, UK; \\ ${ }^{3}$ Family Physician Airways Group of \\ Canada, Richmond Hill, ON, Canada; \\ ${ }^{4}$ Centre for Clinical Trials and Health \\ Research, Plymouth University, \\ Plymouth, ${ }^{5}$ Norfolk Community \\ Health and Care NHS Trust, Norwich, \\ ${ }^{6}$ Primary Care Research, University of \\ Southhampton, Southhampton, UK
}

Correspondence: David Price Academic Centre of Primary Care, University of Aberdeen, Polwarth

Building, Foresterhill,

Aberdeen, AB25 2ZD, UK

Tel +44 I2 24554588

Fax +44 I2 24550683

Email david@respiratoryresearch.org
This article was published in the following Dove Press journal:

Journal of Asthma and Allergy

14 January 2015

Number of times this article has been viewed

\begin{abstract}
Background: Randomized controlled trials indicate that addition of a long-acting muscarinic antagonist (LAMA) such as tiotropium may improve asthma control and reduce exacerbation risk in patients with poorly controlled asthma, but broader clinical studies are needed to investigate the effectiveness of LAMA in real-life asthma care.
\end{abstract}

Methods: Medical records of adults with asthma (aged $\geq 18$ years) prescribed tiotropium were obtained from the UK Optimum Patient Care Research Database for the period 2001-2013. Patients diagnosed with chronic obstructive pulmonary disease were excluded, but no other clinical exclusions were applied. Two primary outcomes were compared in the year before (baseline) and the year after (outcome) addition of tiotropium: exacerbations (asthma-related hospital emergency department attendance or inpatient admission, or acute oral corticosteroid course) and acute respiratory events (exacerbation or antibiotic prescription with lower respiratory consultation). Secondary outcomes included lung function test results and short-acting $\beta_{2}$ agonist usage. The Wilcoxon signed-rank test was used for variables measured on the interval scale, the marginal homogeneity test for categorized variables, and the paired $t$-test for lung function indices.

Results: Of the 2,042 study patients, $83 \%$ were prescribed an inhaled corticosteroid and $68 \%$ a long-acting $\beta_{2}$ agonist during the baseline year; $67 \%$ were prescribed both. Comparing baseline and outcome years, the percentage of patients having at least one exacerbation decreased from $37 \%$ to $27 \%(P<0.001)$ and the percentage having at least one acute respiratory event decreased from $58 \%$ to $47 \%(P<0.001)$. There were no significant changes in lung function, and usage of short-acting $\beta_{2}$ agonists (in salbutamol/albuterol equivalents) increased from a median (interquartile range) of $274(110,548)$ to $329(110,603) \mu \mathrm{g} /$ day $(P=0.01)$.

Conclusion: In this real-life asthma population, addition of LAMA therapy was associated with significant decreases in the incidence of exacerbations and antibiotic prescriptions for lower respiratory tract infections in the following year.

Keywords: anticholinergic, bronchodilator, exacerbation, asthma control, oral corticosteroids

\section{Introduction}

Tiotropium bromide is an anticholinergic drug, categorized as a long-acting muscarinic antagonist (LAMA) or long-acting anticholinergic bronchodilator. ${ }^{1}$ These drugs are used primarily in the management of chronic obstructive pulmonary disease (COPD), but interest in LAMA for the treatment of asthma has increased in recent years, particularly for patients whose asthma is poorly controlled with inhaled corticosteroids (ICS) and long-acting $\beta_{2}$ agonists (LABA). ${ }^{1-4}$ Despite clear guidelines and a range of available treatments, at least $50 \%$ of asthma patients continue to experience poor submit your manuscript | www.dovepress.com

Dovepress

http://dx.doi.org//0.2147/JAA.S76639
Journal of Asthma and Allergy 2015:8 I-13

(c) (i) (5) $\odot 2015$ Price et al. This work is published by Dove Medical Press Limited, and licensed under Creative Commons Attribution - Non Commercial (unported, v3.0) License. The full terms of the License are available at http://creativecommons.org/licenses/by-nc/3.0/. Non-commercial uses of the work are permitted without any further permissin how to request permission may be found at: http://www.dovepress.com/permissions.php 
control of their current symptoms or future exacerbations, which significantly compromises the patient's quality of life and places considerable strain on health care systems. ${ }^{1,4}$ Thus, there is a need for additional therapeutic options.

The mechanisms by which LAMA have the potential to improve asthma control have recently been reviewed. ${ }^{1}$ Briefly, LAMA may: induce bronchodilation, or inhibit cholinergically-mediated bronchoconstriction, and with regular use inhibit the airway smooth muscle hypertrophy and hyper-responsiveness characteristic of chronic asthma; reduce cholinergically-mediated mucus secretion and inhibit goblet cell hyperplasia and mucus gland hypertrophy; and moderate leukocyte responses in the lower airways as well as proinflammatory gene expression by airway smooth muscle and bronchial epithelium. In addition, LAMA such as tiotropium may act as steroid-sparing agents in patients with severe or poorly controlled asthma, ${ }^{5,6}$ which may alleviate some of the burden of corticosteroid use on health-related quality of life in these patients. ${ }^{7}$

A formulation of tiotropium delivered by soft mist inhaler has recently been approved in the $\mathrm{UK}^{8}$ and in several other countries for add-on maintenance therapy in adults with asthma, specifically for patients who are currently treated with ICS and LABA yet experienced at least one severe exacerbation in the past year. Regulatory approval was based on the results of randomized controlled trials (RCTs) in patients with asthma which showed that addition of tiotropium to the existing controller regimen (ICS \pm LABA) improved lung function, , $, 3,9-13$ and may improve symptom control ${ }^{3,11,13}$ and lower the patient's exacerbation risk, ${ }^{3}$ although it did not alter the use of rescue medications such as short-acting $\beta_{2}$ agonists (SABAs). 2,3,10,13

However, these RCTs involved highly selected patient populations (for example, nonsmokers with no serious comorbidities) managed in tightly controlled settings, in most cases with relatively small patient numbers and short study periods. ${ }^{2,9-13}$ Their broader applicability requires the support of clinical studies that better represent real-life populations and situations. ${ }^{14}$ Clinical studies on the effectiveness of LAMA as add-on therapy in real-life asthma care are still needed.

To that end, we examined the clinical effects of add-on therapy with tiotropium in a diverse group of over 2,000 asthma patients treated in UK primary care practice. Study patients were at least 18 years of age and had a physician-recorded diagnosis of asthma; patients with a recorded diagnosis of COPD were excluded, but no other clinically relevant exclusions were applied. By comparing exacerbation rates and other measures of asthma control in the year before and after the addition of tiotropium to the patient's asthma regimen, our goal was to determine whether the addition of LAMA improves asthma control in routine clinical practice.

\section{Materials and methods}

This historical, observational study of UK asthma patients used data obtained from the Optimum Patient Care Research Database (OPCRD; http://www.optimumpatientcare.org), which contains more than 5 million anonymized, longitudinal patient records from approximately 400 participating medical practices in the UK and is focused on patients with evidence of respiratory disease. The OPCRD has been approved by the Trent Multicentre Research Ethics Committee for use in clinical research, and the protocol for this study was approved by the Anonymised Data Ethics Protocols and Transparency Committee, which is the independent scientific advisory committee for the OPCRD.

Data were examined for the period 2001-2013. The medical record of each study patient was examined for the 12 months before (baseline) and 12 months after (outcome) the date of the patient's first prescription for tiotropium (index prescription date); hence, the index prescription dates spanned 2002-2012. Other LAMA drugs became available in the UK towards the end of the study period, but in the interest of investigating LAMA use in as many asthma patients as possible while using well-defined criteria, we limited the index prescription to tiotropium.

Two formulations of tiotropium bromide for inhalation were available in the UK during the study period: a drypowder inhaler with a recommended dosage of $10 \mu \mathrm{g}$ (the dose delivered from one $18 \mu \mathrm{g}$ capsule) once a day ${ }^{15}$ and a soft mist inhaler with a recommended dosage of $5 \mu \mathrm{g}$ (two puffs of $2.5 \mu \mathrm{g}$ ) once a day. ${ }^{8}$ Although equivalence data are not yet available for patients with asthma, these formulations and dosages have comparable bronchodilator efficacy in patients with COPD, ${ }^{16,17}$ so we chose to study the patients as a group, regardless of formulation/dosage.

The study patients had at least one prescription for tiotropium during the study window, had a recorded diagnosis of asthma, had no recorded diagnosis of COPD, were at least 18 years of age at the index prescription date, and had two continuous years of data (12 months each of baseline and outcome data). Figure 1 illustrates the patient selection process and study design. 


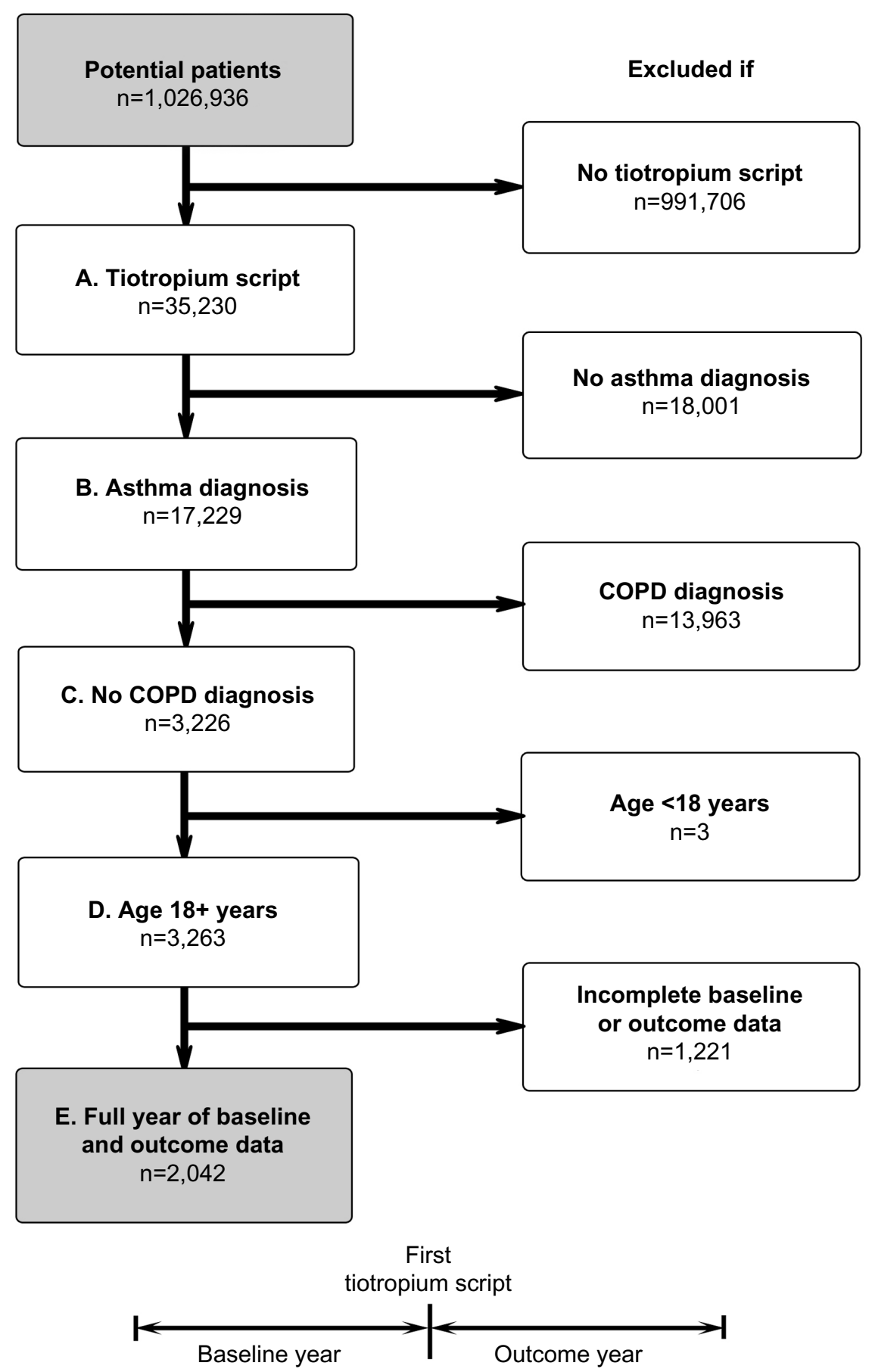

Figure I Patient selection process and study design. Inclusion criteria: (A) at least one prescription for tiotropium, (B) recorded diagnosis of asthma, (C) no recorded diagnosis of COPD, (D) at least 18 years of age at first tiotropium prescription, and (E) full 12 months of data before (baseline) and after (outcome) first tiotropium prescription. Abbreviation: COPD, chronic obstructive pulmonary disease.

\section{Effectiveness measures}

The baseline year was used for patient characterization and the outcome year for evaluation of asthma-related effectiveness measures. A complete list of the baseline variables examined is provided in the Supplementary materials (Table S1), along with their definitions and methods of calculation.
The effectiveness measures compared before and after addition of tiotropium are described in Table 1. The two primary outcomes were exacerbations and acute respiratory events. We used the American Thoracic Society and European Respiratory Society definition of an exacerbation (asthmarelated urgent hospital attendance/admission or acute course 
Table I Effectiveness measures compared before and after addition of tiotropium

\begin{tabular}{|c|c|}
\hline Variable & Definition \\
\hline \multicolumn{2}{|l|}{ Primary } \\
\hline Exacerbations & $\begin{array}{l}\text { Number of exacerbations, defined as } \\
\text { occurrence of one of the following: } \\
\text { I. Asthma-related urgent hospital visit (A\&E or } \\
\text { inpatient) } \\
\text { 2. Acute OCS course with evidence of LRT } \\
\text { consultation }\end{array}$ \\
\hline $\begin{array}{l}\text { Acute respiratory } \\
\text { events }\end{array}$ & $\begin{array}{l}\text { Number of events, defined as occurrence of } \\
\text { one of the following: } \\
\text { I. Exacerbation } \\
\text { 2. Antibiotic prescription with evidence of LRT } \\
\text { consultation }\end{array}$ \\
\hline \multicolumn{2}{|l|}{ Secondary } \\
\hline $\begin{array}{l}\text { Risk domain of } \\
\text { asthma control }\end{array}$ & $\begin{array}{l}\text { Controlled/uncontrolled } \\
\text { Controlled if absence of all the following: } \\
\text { I. Asthma-related hospital visit (A\&E, inpatient, } \\
\text { or outpatient) } \\
\text { 2. Acute OCS course with evidence of LRT } \\
\text { consultation } \\
\text { 3. Antibiotic prescription with evidence of LRT } \\
\text { consultation } \\
\text { Uncontrolled if any such events occurred in the } \\
\text { year of interest }\end{array}$ \\
\hline $\begin{array}{l}\text { Acute OCS } \\
\text { courses }\end{array}$ & $\begin{array}{l}\text { Number of acute OCS courses with evidence of } \\
\text { LRT consultation }\end{array}$ \\
\hline $\begin{array}{l}\text { Antibiotic } \\
\text { prescriptions }\end{array}$ & $\begin{array}{l}\text { Number of antibiotic prescriptions with } \\
\text { evidence of LRT consultation }\end{array}$ \\
\hline PEF (\% predicted $)^{\mathrm{b}}$ & $\begin{array}{l}\text { Peak expiratory flow (PEF), expressed as } \\
\text { percentage of predicted normal }\end{array}$ \\
\hline $\mathrm{FEV}_{1}(\% \text { predicted })^{\mathrm{b}}$ & $\begin{array}{l}\text { Forced expiratory volume in one second }\left(\mathrm{FEV}_{1}\right) \text {, } \\
\text { expressed as percentage of predicted normal }\end{array}$ \\
\hline $\mathrm{FEV}_{1} / \mathrm{FVC}$ ratio $^{\mathrm{b}}$ & Ratio of FEV, to forced vital capacity (FVC) \\
\hline SABA usage & $\begin{array}{l}\text { Prescribed SABA dosage, averaged over the } \\
\text { year of interest, in salbutamol (albuterol) } \\
\text { equivalents }\end{array}$ \\
\hline
\end{tabular}

Notes: any lower respiratory consultation (asthma, COPD, or LRT infection code, or lung function/asthma monitoring) with additional respiratory examinations, including chest $\mathrm{X}$-rays and referrals; ${ }^{b}$ when paired baseline and outcome data were available.

Abbreviations: A\&E, Accident and Emergency Department; COPD, chronic obstructive pulmonary disease; LRT, lower respiratory tract; OCS, oral corticosteroid; SABA, short-acting $\beta_{2}$ agonist.

of systemic corticosteroids), ${ }^{18}$ although we limited systemic corticosteroid use to an acute course of oral corticosteroids (OCS) accompanied by a lower respiratory consultation (physician visit coded as asthma, COPD, lower respiratory tract infection, or lung function/asthma monitoring, with further respiratory examination, thoracic radiographs, or referral). An acute respiratory event was defined as either an exacerbation or an antibiotic prescription accompanied by a lower respiratory consultation (which was taken to indicate that the physician treated the episode as a lower respiratory tract infection). Multiple qualifying events within a 2-week window were counted as a single exacerbation or acute respiratory event.

Secondary measures included the risk domain of asthma control (a proxy measure of asthma control as it pertains to exacerbation risk), specific components of the primary effectiveness measures (asthma-related acute OCS and antibiotic use), peak expiratory flow (PEF), forced expiratory volume in one second $\left(\mathrm{FEV}_{1}\right)$, the ratio of $\mathrm{FEV}_{1}$ to forced vital capacity (FVC), and SABA usage. Asthma control in the risk domain was achieved if there were no episodes of asthma-related hospital, OCS, or antibiotic usage in the year of interest. As the measure of SABA usage, the prescribed SABA dosage was averaged over the year of interest, with all SABA dosages converted to salbutamol (albuterol) equivalents (Table S1).

\section{Statistical analysis}

The statistical analysis was conducted using Statistical Package for the Social Sciences version 21 software (IBM Corporation, Armonk, NY, USA) and Microsoft Excel 2007 (Microsoft Corporation, Redmond, WA, USA). Statistical significance was defined as $P<0.05$. Mean values are presented with their standard deviations and median values with their interquartile ranges (25th and 75 th percentiles). Where data were not normally distributed, median (interquartile range) values are reported.

Summary statistics were generated for all baseline and outcome variables. The number of exacerbations in the year before and after initiating tiotropium was then compared using the Wilcoxon signed-rank test for exacerbation counts measured on the interval scale and the marginal homogeneity test for categorized exacerbation data. These tests were also used to compare baseline and outcome years for acute respiratory events, acute OCS courses, antibiotic prescriptions, and SABA usage. The paired $t$-test was used to compare baseline and outcome years for PEF and $\mathrm{FEV}_{1}$, and the marginal homogeneity test was used for comparison of categorized $\mathrm{FEV}_{1} / \mathrm{FVC}$ ratios. The proportion of patients achieving asthma control in the risk domain was compared between baseline and outcome years using the McNemar test.

\section{Sensitivity analysis}

Although the selection process deliberately excluded asthma patients who also had a recorded diagnosis of COPD, some patients with undiagnosed or unrecorded COPD may have been included, given the average age of the study patients and the prevalence of current or former smokers. For this reason, the primary analyses (exacerbations and acute respiratory events) were repeated for a subset of patients 
who were unlikely to have COPD based on the following criteria: $\leq 40$ years of age, $>40$ years of age but never smoked, and $>40$ years of age with no evidence of airway obstruction (baseline $\mathrm{FEV}_{1} / \mathrm{FVC}$ ratio $\geq 0.7$ ).

\section{Results}

A total of 2,042 patients met the study criteria. The dry powder formulation of tiotropium was prescribed in 1,898 patients $(93 \%)$ and the soft mist inhaler in 144 patients $(7 \%)$. Key baseline patient characteristics are summarized in Tables 2 and 3; complete baseline data are provided in the Supplementary materials (Tables S2-S6). The mean age was 63 years; $59 \%$ of patients were female; the mean body mass index was $29 \mathrm{~kg} / \mathrm{m}^{2}$; and of those whose smoking history was known, $54 \%$ were either current $(17 \%)$ or former (37\%) smokers. In the patients with baseline lung function data, the mean PEF was $69 \%$ of predicted normal, the mean

Table 2 Key descriptive characteristics at baseline

\begin{tabular}{|c|c|}
\hline \multicolumn{2}{|l|}{ Age (years) } \\
\hline Mean (SD) & $63.4(14.2)$ \\
\hline$>40$ years, $n(\%)$ & I,906 (93.3\%) \\
\hline Gender, female; n (\%) & I,208 (59.2\%) \\
\hline BMI (kg/m²); n (\%) & I,959 (95.6\%) \\
\hline Mean (SD) & $29.2(6.7)$ \\
\hline Overweight, n (\%) & $664(33.9 \%)^{\mathrm{a}}$ \\
\hline Obese, n (\%) & $765(39.1 \%)^{\mathrm{a}}$ \\
\hline Smoking status, known; n (\%) & $\mathrm{I}, 853$ (90.7\%) \\
\hline Nonsmoker & $849(45.8 \%)^{\mathrm{a}}$ \\
\hline Current smoker & $322(17.4 \%)^{a}$ \\
\hline Ex-smoker & $682(36.8 \%)^{\mathrm{a}}$ \\
\hline PEF (\% predicted), n (\%) & $\mathrm{I}, 358(66.5 \%)$ \\
\hline Mean (SD) & $69.3(21.8)$ \\
\hline $\mathrm{FEV}_{1}$ (\% predicted), n (\%) & $848(41.5 \%)$ \\
\hline Mean (SD) & $59.0(29.0)$ \\
\hline $\mathrm{FEV}_{1} / \mathrm{FVC}$ ratio, $\mathrm{n}(\%)$ & $780(38.2 \%)$ \\
\hline Mean (SD) & $0.6 \mathrm{I}(0.24)$ \\
\hline$\geq 0.7, \mathrm{n}(\%)$ & $311(39.9 \%)^{a}$ \\
\hline ICS prescribed, n (\%) & $1,690(82.8 \%)$ \\
\hline LABA prescribed, n (\%) & I,385 (67.8\%) \\
\hline Adherence to ICS (\%), n (\%) & $\mathrm{I}, 690(82.8 \%)$ \\
\hline Median (IQR) & $100(73,134)$ \\
\hline Controller-reliever ratio, n (\%) & I,909 (93.5\%) \\
\hline Median (IQR) & $0.50(0.33,0.71$ \\
\hline \multicolumn{2}{|l|}{ Hospitalization, $\geq \mathrm{I}^{\mathrm{b}}$; n (\%) } \\
\hline$A \& E$ & $25(1.2 \%)$ \\
\hline Inpatient & $22(1.1 \%)$ \\
\hline Outpatient & $22(1.1 \%)$ \\
\hline
\end{tabular}

Notes: $n=2,042$, unless otherwise noted; apercentage of patients with data for that variable; bat least one asthma-related hospital visit during baseline year (categorized).

Abbreviations: A\&E, Accident and Emergency Department; BMI, body mass index; $\mathrm{FEV}_{1}$, forced expiratory volume in one second, expressed as percentage of predicted normal; FVC, forced vital capacity; ICS, inhaled corticosteroid; IQR, interquartile range; LABA, long-acting $\beta_{2}$ agonist; PEF, peak expiratory flow, expressed as percentage of predicted normal; SD, standard deviation.
Table 3 Comparison of effectiveness measures before (baseline) and after (outcome) addition of tiotropium

\begin{tabular}{|c|c|c|c|}
\hline & Baseline & Outcome & $P$-value ${ }^{a}$ \\
\hline \multicolumn{4}{|l|}{ Exacerbations } \\
\hline$\geq \mathrm{I}, \mathrm{n}(\%)$ & $752(36.8 \%)$ & $543(26.6 \%)$ & $<0.001$ \\
\hline \multicolumn{4}{|l|}{ Acute respiratory events } \\
\hline$\geq \mathrm{I}, \mathrm{n}(\%)$ & I,I9I (58.3\%) & 965 (47.3\%) & $<0.001$ \\
\hline \multicolumn{4}{|l|}{$\begin{array}{l}\text { Risk domain of asthma } \\
\text { control }\end{array}$} \\
\hline Controlled, n (\%) & $846(4 I .4 \%)$ & I,07| (52.4\%) & $<0.00 \mathrm{I}^{\mathrm{b}}$ \\
\hline \multicolumn{4}{|l|}{ Acute OCS courses } \\
\hline$\geq \mathrm{I}, \mathrm{n}(\%)$ & $732(35.8 \%)$ & $52 ।(25.5 \%)$ & $<0.001$ \\
\hline \multicolumn{4}{|l|}{ Antibiotic prescriptions } \\
\hline$\geq \mathrm{I}, \mathrm{n}(\%)$ & I,043 (5I.1\%) & $842(4 \mid .2 \%)$ & $<0.001$ \\
\hline PEF (\% predicted), n (\%) & $926(45.3 \%)$ & $926(45.3 \%)$ & \\
\hline Mean (SD) & $70.0(21.5)$ & $69.5(21.7)$ & $0.37 I^{c}$ \\
\hline $\mathrm{FEV}_{1}(\%$ predicted), n (\%) & $398(19.5 \%)$ & $398(19.5 \%)$ & \\
\hline Mean (SD) & $58.0(29.5)$ & $57.9(30.5)$ & $0.935^{c}$ \\
\hline $\mathrm{FEV}_{\mathrm{I}} / \mathrm{FVC}$ ratio, n (\%) & $353(17.3 \%)$ & $353(17.3 \%)$ & \\
\hline$<0.5, \mathrm{n}(\%)^{d}$ & 91 (25.8\%) & $116(32.9 \%)$ & 0.382 \\
\hline $0.5-0.69, \mathrm{n}(\%)^{\mathrm{d}}$ & $122(34.6 \%)$ & $86(24.4 \%)$ & \\
\hline$\geq 0.7, \mathrm{n}(\%)^{d}$ & $140(39.7 \%)$ & $15 \mid(42.8 \%)$ & \\
\hline \multicolumn{4}{|l|}{ SABA usage $(\mu g / \text { day })^{e}$} \\
\hline Median (IQR) & $274(110,548)$ & $329(110,603)$ & $0.010^{f}$ \\
\hline
\end{tabular}

Notes: $n=2,042$ unless otherwise noted; ${ }^{a}$ marginal homogeneity test, unless

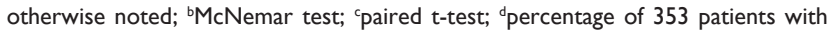
paired FEV,/FVC ratio data; 'in salbutamol (albuterol) equivalents; 'Wilcoxon signedrank test.

Abbreviations: $\mathrm{FEV}_{1}$, forced expiratory volume in one second, expressed as percentage of predicted normal; FVC, forced vital capacity; IQR, interquartile range; OCS, oral corticosteroid; PEF, peak expiratory flow, expressed as percentage of predicted normal; SABA, short-acting $\beta_{2}$ agonist; SD, standard deviation.

$\mathrm{FEV}_{1}$ was $59 \%$ of predicted normal, and the mean $\mathrm{FEV}_{1} / \mathrm{FVC}$ ratio was 0.61 ; only $40 \%$ of the patients with $\mathrm{FEV}_{1}$ and $\mathrm{FVC}$ data had a ratio $\geq 0.7$.

At baseline, most patients were being treated according to British Thoracic Society guidelines ${ }^{19}$ step 3 (21.5\%) or step 4 (49.5\%; Table S5). An ICS was prescribed in $83 \%$ of patients and a LABA in $68 \%$ of patients; $67 \%$ were prescribed both (Table S5). Median adherence to ICS therapy (Table S1) was $100 \%$, with $51 \%$ of patients having $\geq 100 \%$ adherence (Table S5). The median controller-reliever ratio (Table S1) was 0.5 , indicating approximately equal use of controller (ICS or leukotriene receptor antagonist) and reliever (SABA) medications, although $59 \%$ of patients had a ratio $\geq 0.5$ (Table S5), indicating relatively more controller than reliever use. During their baseline year, $37 \%$ of patients had at least one exacerbation, $58 \%$ had at least one acute respiratory event, and $41 \%$ achieved asthma control in the risk domain (Table 3).

\section{Outcomes}

Comparisons between baseline and outcome years for the various effectiveness measures are summarized in Table 3 
and illustrated in Figures 2-4, with further details provided in Table S6. Addition of tiotropium was associated with significantly fewer exacerbations (Figure 2) and acute respiratory events (Figure 3); $27 \%$ of patients had at least one exacerbation, $47 \%$ had at least one acute respiratory event, and $52 \%$ achieved asthma control in the risk domain during the outcome year (Table 3). In addition, tiotropium use was associated with significantly less asthma-related acute OCS and antibiotic use (Tables 3 and S6). Comparing baseline and outcome years, SABA usage significantly increased (Figure 4), but there were no significant changes in PEF, $\mathrm{FEV}_{1}$, or $\mathrm{FEV}_{1} / \mathrm{FVC}$ ratio in the patients with paired baseline and outcome data for those variables (Table 3).

\section{Sensitivity analysis}

The sensitivity analysis was conducted on 928 patients ( $45 \%$ of the full study group) with the least likelihood of also having COPD. Baseline characteristics are summarized in Table 4 , distributed by age group ( $\leq 40$ and $>40$ years). Compared with the full study group, proportionately more patients in this subset were female (65\%) and nonsmokers $(76 \%)$, and fewer were current $(9 \%)$ or former $(15 \%)$ smokers. The mean $\mathrm{FEV}_{1} / \mathrm{FVC}$ ratio was 0.8 . The rates of exacerbations and acute respiratory events during the baseline year were comparable with those of the full study group, and the addition of tiotropium was associated with a similar decrease in exacerbations and acute respiratory events during the outcome year (Tables 5 and S7).

\section{Discussion}

Our study showed that primary care physicians in the UK have been prescribing LAMA for the treatment of asthma since 2002, even though there were no UK license or guideline recommendations for LAMA use in patients with asthma

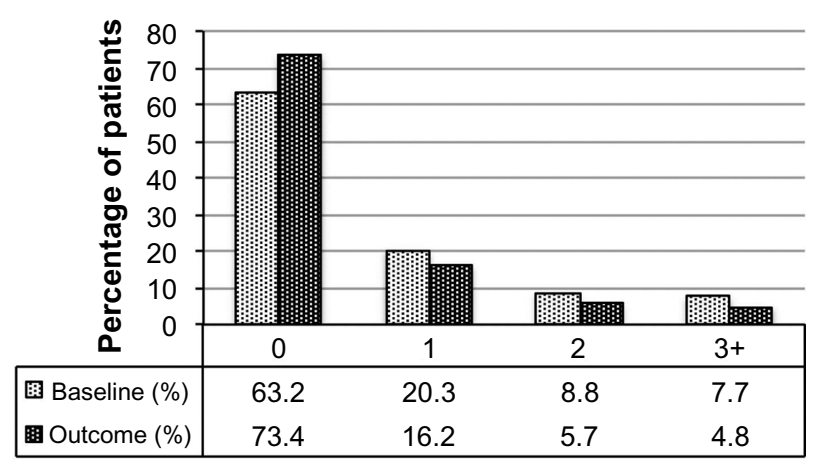

Number of exacerbations

Figure 2 Exacerbation rates before (baseline) and after (outcome) addition of tiotropium. $P<0.001$ (marginal homogeneity test) comparing baseline and outcome years.

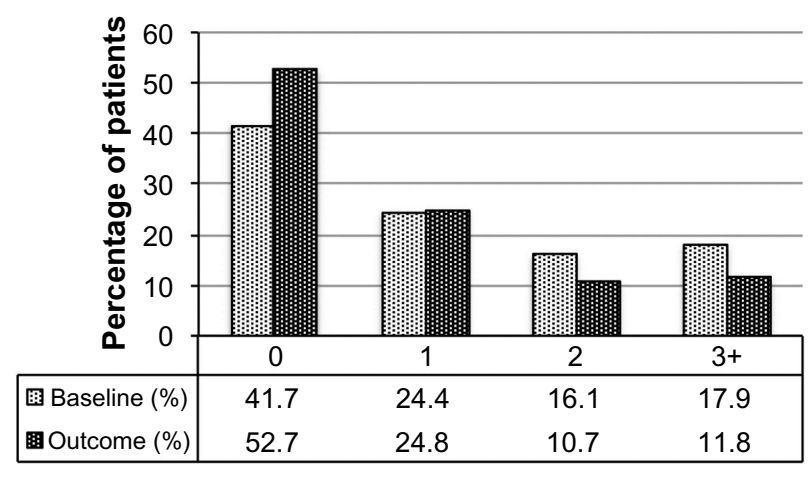

Number of acute respiratory events

Figure 3 Acute respiratory events before (baseline) and after (outcome) addition of tiotropium. $P<0.001$ (marginal homogeneity test) comparing baseline and outcome years.

until September 2014. ${ }^{15}$ It was not possible with our study design to determine why a LAMA was prescribed in these patients. However, $93 \%$ of the patients were over 40 years of age and $62 \%$ were over 60 years of age, more than $50 \%$ of whom were current or former smokers (Table S3). Most had significant comorbidities (Table S2), and many had impairments of lung function and asthma control in the risk domain despite treatment with moderate to high doses of ICS $\pm \mathrm{LABA}, \geq 100 \%$ adherence to their ICS prescriptions, and controller-reliever ratios indicative of equal or greater use of controller medications throughout the year. Thus, it appears that physicians were prescribing LAMA predominantly as add-on therapy in older patients with poorly controlled asthma despite good treatment compliance, particularly in those who were current or former smokers.

In this population, addition of tiotropium was associated with a significant decrease in the incidence of exacerbations and other acute respiratory events (specifically, antibiotic

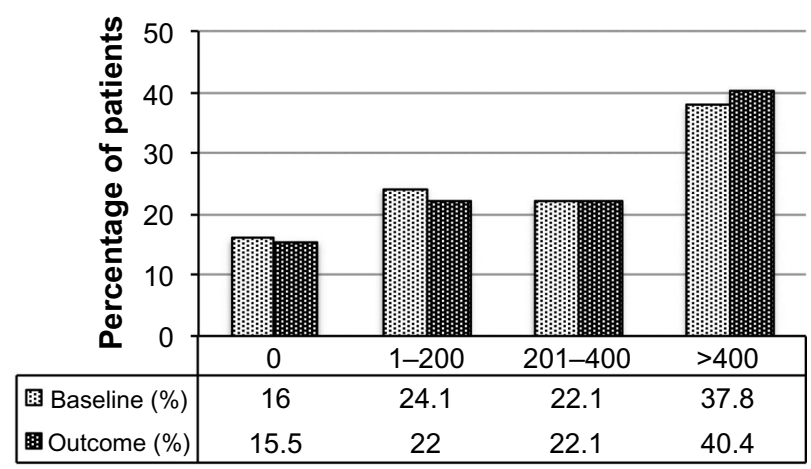

\section{Average SABA dosage ( $\mu \mathrm{g} /$ day)}

Figure 4 SABA usage before (baseline) and after (outcome) addition of tiotropium. Dosages are in salbutamol (albuterol) equivalents; $P=0.006$ (marginal homogeneity test) comparing baseline and outcome years.

Abbreviation: SABA, short-acting $\beta_{2}$ agonist. 
Table 4 Sensitivity analysis: baseline patient characteristics

\begin{tabular}{llll}
\hline Variable & Total & $\begin{array}{l}\text { Age } \\
\leq \mathbf{4 0} \text { years }\end{array}$ & $\begin{array}{l}\text { Age } \\
>\mathbf{4 0} \text { years }\end{array}$ \\
\hline Age (years), n (\%) & $928(100 \%)$ & $136(14.7 \%)$ & $792(85.3 \%)$ \\
$\quad$ Mean (SD) & $61.3(16.3)$ & $33.6(5.8)$ & $66.1(12.2)$ \\
Gender, female; n (\%) & $60 I(64.8 \%)$ & $97(16.1 \%)$ & $504(83.9 \%)$ \\
Smoking status, known; & $884(95.3 \%)$ & $123(13.9 \%)^{\mathrm{a}}$ & $761(86.1 \%)^{\mathrm{a}}$ \\
n (\%) & & & \\
Nonsmoker & $674(76.2 \%)^{\mathrm{b}}$ & $58(8.6 \%)$ & $616(91.4 \%)$ \\
$\quad$ Current smoker & $79(8.9 \%)^{\mathrm{b}}$ & $39(49.4 \%)$ & $40(50.6 \%)$ \\
$\quad$ Ex-smoker & $131(14.8 \%)^{\mathrm{b}}$ & $26(19.8 \%)$ & $105(80.2 \%)$ \\
PEF (\% predicted); n (\%) & $615(66.3 \%)$ & $89(14.5 \%)$ & $526(85.5 \%)$ \\
$\quad$ Mean (SD) & $72.8(22.1)$ & $67.4(20.1)$ & $73.7(22.3)$ \\
FEV $(\%$ predicted); n (\%) & $35 \mathrm{I}(37.8 \%)$ & $43(12.3 \%)$ & $308(87.7 \%)$ \\
$\quad$ Mean (SD) & $74.9(27.5)$ & $59.6(25.2)$ & $77.0(27.2)$ \\
FEV /FVC ratio, n (\%) & $328(35.3 \%)$ & $40(12.2 \%)$ & $288(87.8 \%)$ \\
$\quad$ Mean (SD) & $0.8(0.2)$ & $0.7(0.3)$ & $0.8(0.2)$ \\
\hline
\end{tabular}

Notes: aWithin-row percentages for the two age groups represent percentage of the total number of patients in that row; bercentage of 884 patients whose smoking status was known.

Abbreviations: $\mathrm{FEV}_{1}$, forced expiratory volume in one second, expressed as percentage of predicted normal; FVC, forced vital capacity; PEF, peak expiratory flow, expressed as percentage of predicted normal; SD, standard deviation.

prescriptions for lower respiratory tract infection), and a significant increase in the rate of asthma control in the risk domain over the following year. Whereas most of the aforementioned clinical trials emphasized current symptom control, our study was focused primarily on the effects of LAMA on the patient's exacerbation risk, as exacerbations have such a negative impact on the patient's quality of life and on health care resources. ${ }^{20}$ The RCT by Kerstjens et al ${ }^{3}$ showed a significant reduction in exacerbation risk with the addition of tiotropium; however, their patient population was younger than our study group by about 10 years (mean age, 53 years), $76 \%$ of their patients had never smoked, the remainder had a smoking history of $<10$ pack-years, and none of their patients had serious coexisting illnesses. Thus, it may be particularly noteworthy that in our study LAMA therapy was associated with a decrease in exacerbations even under less-than-ideal conditions. Also of note, LAMA use in our study was associated with a significant reduction in acute OCS use, which may be expected to reduce the multifaceted treatment burden documented for

Table 5 Sensitivity analysis: comparison of primary measures before (baseline) and after (outcome) addition of tiotropium

\begin{tabular}{lccc}
\hline Variable & Baseline & Outcome & $\boldsymbol{P}_{\text {-value }}$ \\
\hline $\begin{array}{l}\text { Exacerbations } \\
\quad \geq \mathrm{I}, \mathrm{n}(\%)\end{array}$ & $363(39.1 \%)$ & $274(29.5 \%)$ & $<0.00 \mathrm{I}$ \\
$\begin{array}{l}\text { Acute respiratory events } \\
\geq \mathrm{I}, \mathrm{n}(\%)\end{array}$ & $567(6 \mathrm{I} . \mathrm{l} \%)$ & $452(48.7 \%)$ & $<0.00 \mathrm{I}$ \\
\hline
\end{tabular}

Notes: $n=928$; amarginal homogeneity test. corticosteroid use in patients with severe or poorly controlled asthma. ${ }^{?}$

Given our study design, it may be argued that regression toward the mean could have contributed to the differences found between baseline and outcome years. This issue may have been obviated by using a matched control group not prescribed tiotropium, although such an approach would almost certainly have led to the loss of unmatched but otherwise qualified patients prescribed tiotropium and thus to a smaller number and perhaps less diverse group of patients for study. As it was, our study design involved data collected over 2 consecutive years within a continuum of ongoing therapy in long-term asthma patients that, for the group, spanned over a decade (2001-2013); and with the exception of the lung function indices, the baseline and outcome values each represented a full year of data, not repeated measures of single, isolated points in time. Thus, if regression toward the mean was a factor in our study results, its influence was likely small. Furthermore, our findings are supported by those of Kerstjens et al, ${ }^{3}$ who showed in two replicate, randomized, double-blind, placebo-controlled, parallel-group clinical trials involving 48-week study periods and 912 patients in 15 countries that addition of tiotropium significantly increased the time to first exacerbation and decreased the exacerbation risk in patients whose asthma was poorly controlled despite maintenance treatment with ICS and LABA.

A legitimate concern, given our study design and patient demographics, is that the group may have included some asthma patients who also had undiagnosed or unrecorded COPD. The sensitivity analysis, limited to the patients least likely to have COPD, was conducted to address this issue. In this subset, addition of tiotropium was associated with decreases in the incidence of exacerbations and other acute respiratory events (specifically, antibiotic prescriptions for lower respiratory tract infection) similar to that found in the full study group. Thus, it is reasonable to conclude that LAMA therapy may be associated with a decrease in asthma exacerbations whether or not the patient may also have COPD.

A further criticism is that no separate control or comparator group was included, and treatment was not randomized. Our study purpose was to retrospectively examine the outcomes of clinical decisions made by primary care physicians with regard to the use of LAMA therapy in real-life patients with asthma. There was therefore no opportunity for us to randomize treatment, and as discussed above, our decision not to include a matched control group was made deliberately and with the goal of generating as large and diverse a 
treatment group as possible. Thus, our study patients served as their own controls, the comparisons in asthma-related effectiveness measures being made between the year before and the year after initiating LAMA therapy. Despite this and other limitations imposed by our study design, our findings are generally consistent with those of the RCTs that included placebo ${ }^{2,3,9-12}$ or comparator drug groups. ${ }^{10,13}$

Yet another potential shortcoming of our study design is that not all study patients had lung function data, and in those who did, no constraints could be placed on the timing of the lung function tests with regard to time of day (morning or evening) or bronchodilator administration (before or after bronchodilation), when the tests were performed in the outcome year relative to initiation of tiotropium therapy, nor on quality control of the measurements. In comparison, licensing studies require centralized spirometry over-reading to ensure high quality spirometry. In order to maximize patient numbers, we elected not to limit the study group to only those patients with paired lung function data. Physicians evidently were prescribing LAMA for patients with asthma even in the absence of lung function tests, so our full study group reflects recent clinical practices and outcomes.

The inability to dictate the timing and performance of the lung function tests in our study likely contributed to the large variations found in lung function values. Along with patient age and inclusion of smokers, that may explain the lack of significant changes in lung function with the addition of tiotropium, when improvements in lung function were a consistent RCT finding. ${ }^{2,3,9-13}$ It is worth noting, however, that the RCT improvements in lung function with the addition of tiotropium, while statistically significant, often were small, and they were not consistently accompanied by improvements in asthma control or quality of life. . $3,3,12,13^{2}$

Between baseline and outcome years, the change in SABA usage in our study group, while statistically significant, was small and may be considered of little clinical relevance. This finding is consistent with RCT results for tiotropium use in patients with asthma, ${ }^{2,3,10,13}$ but it is somewhat at odds with the classification of tiotropium as a long-acting bronchodilator that is administered once daily, ${ }^{8,15}$ and with the proposed mechanisms by which LAMA may improve asthma control. ${ }^{1}$ A longer investigation period may be required to determine whether or not LAMA perform in practice as these mechanisms propose. In the meantime, it is useful to know that addition of tiotropium to the current treatment regimen may reduce the asthma patient's exacerbation risk within the first year of treatment.

\section{Conclusion}

In this real-life population of adults with asthma treated in routine clinical practice, addition of a LAMA to the current treatment regimen was associated with a decrease in exacerbations and other acute respiratory events (specifically, antibiotic prescriptions for lower respiratory tract infections) in the following year.

\section{Acknowledgment}

This study was funded solely by Research in Real-Life, Cambridge, UK.

\section{Disclosure}

DP: board membership with Aerocrine, Almirall, Amgen, AstraZeneca, Boehringer Ingelheim, Chiesi, Meda, Mundipharma, Napp, Novartis, and Teva; consultancy with Almirall, Amgen, AstraZeneca, Boehringer Ingelheim, Chiesi, GlaxoSmithKline, Meda, Mundipharma, Napp, Novartis, Pfizer, and Teva; grants/pending grants with UK National Health Service, British Lung Foundation, Aerocrine, AstraZeneca, Boehringer Ingelheim, Chiesi, Eli Lilly, GlaxoSmithKline, Meda, Merck, Mundipharma, Novartis, Orion, Pfizer, Respiratory Effectiveness Group, Takeda, Teva, and Zentiva; payments for lectures/speaking engagements from Almirall, AstraZeneca, Boehringer Ingelheim, Chiesi, Cipla, GlaxoSmithKline, Kyorin, Meda, Merck, Mundipharma, Novartis, Pfizer, SkyePharma, Takeda, and Teva; payment for manuscript preparation from Mundipharma and Teva; patents (planned, pending, or issued) with AKL Ltd; payment for the development of educational materials for GlaxoSmithKline and Novartis; stock/stock options in AKL Ltd (shares) and in Research in Real Life Ltd (RiRL; 80\% ownership) and its subsidiary social enterprise Optimum Patient Care; payment for travel/accommodation/meeting expenses from Aerocrine, Boehringer Ingelheim, Mundipharma, Napp, Novartis, and Teva; funding for patient enrollment or completion of research from Almirall, Chiesi, Teva, and Zentiva; peer reviewer for grant committees with Efficacy and Mechanism Evaluation program (2012), HTA (2014), and Medical Research Council (2014); and unrestricted funding for investigator-initiated studies from Aerocrine, AKL Ltd, Almirall, Boehringer Ingelheim, Chiesi, Meda, Mundipharma, Napp, Novartis, Orion, Takeda, Teva, and Zentiva.

AK: Neither he nor any member of his close family has any shares in pharmaceutical companies. In the last 3 years he has received speaker's honoraria for speaking at sponsored meetings or satellite symposia at conferences from the following companies marketing respiratory and allergy products: Aerocrine, 
AstraZeneca, Boehringer Ingelheim, GlaxoSmithKline, Griffols, Johnson \& Johnson, Merck Sharp and Dohme, Novartis, Pfizer, Purdue, and Takeda. He has received honoraria for attending advisory panels from Aerocrine, AstraZeneca, Boehringer Ingelheim, GlaxoSmithKline, Novartis, and Takeda. He has received sponsorship to attend international scientific meetings from AstraZeneca and Pfizer.

RJ: In the last 3 years he has received speaker fees, travel expenses, or consultancy fees from Almirall, AstraZeneca, Boehringer Ingelheim, Chiesi, GlaxoSmithKline, Health Intelligence, Napp, Novartis, and Pfizer, and has undertaken research funded by Novartis.

DF: She has no shares in pharmaceutical companies. She has received speaker's honoraria for speaking at sponsored meetings from the following companies marketing respiratory products: Almirall, AstraZeneca, Boehringer Ingelheim, GlaxoSmithKline, Meda, Napp, and Teva. She has received honoraria for advisory panels from Almirall and financial support for conference attendance from Almirall, Napp, and Teva.

MT: Neither he nor any member of his close family has any shares in pharmaceutical companies. In the last 3 years he has received speaker's honoraria for speaking at sponsored meetings or satellite symposia at conferences from the following companies marketing respiratory and allergy products: Aerocrine, AstraZeneca, Boehringer Ingelheim, GlaxoSmithKline, Merck Sharp and Dohme, and Teva. He has received honoraria for attending advisory panels from Aerocrine, Almirall, AstraZeneca, Boehringer Ingelheim, Chiesi, GlaxoSmithKline, Merck Sharp and Dohme, and Novartis. He has received sponsorship to attend international scientific meetings from AstraZeneca, GlaxoSmithKline, and Mundipharma. He has received funding for research projects from Almirall and GlaxoSmithKline. He is chief medical adviser to the charity Asthma UK and a member of the British Thoracic Society SIGN Asthma guideline group and the National Institute for Health and Care Excellence asthma guideline group.

AB, SG, JvZ, and MA are employees of RiRL, which has conducted paid research in respiratory disease on behalf of the following organizations in the past 5 years: Aerocrine, AKL Ltd, Almirall, Boehringer Ingelheim, Chiesi, GlaxoSmithKline, Meda, Mundipharma, Napp, Novartis, Orion, Takeda, Teva, and Zentiva. CK declares that she has no conflicts of interest in relation to this study.

\section{References}

1. Price D, Fromer L, Kaplan A, van der Molen T, Román-Rodríguez M. Is there a rationale and role for long-acting anticholinergic bronchodilators in asthma? NPJ Prim Care Respir Med. 2014;24:14023.
2. Kerstjens HA, Disse B, Schröder-Babo W, et al. Tiotropium improves lung function in patients with severe uncontrolled asthma: a randomized controlled trial. J Allergy Clin Immunol. 2011;128: 308-314.

3. Kerstjens HA, Engel M, Dahl R, et al. Tiotropium in asthma poorly controlled with standard combination therapy. NEngl J Med. 2012;367: 1198-1207.

4. Wilson J, Bateman ED, Pavord I, Lloyd A, Krivasi T, Esser D. Cost effectiveness of tiotropium in patients with asthma poorly controlled on inhaled glucocorticosteroids and long-acting $\beta$-agonists. Appl Health Econ Health Policy. 2014;12:447-459.

5. Kapoor AS, Olsen SR, O'Hara C, Puttagunta L, Vethanayagam D. The efficacy of tiotropium as a steroid-sparing agent in severe asthma. Can Respir J. 2009;16:99-101.

6. Adams KS, Lowe DK. Tiotropium for adults with inadequately controlled persistent asthma. Ann Pharmacother. 2013;47:117-123.

7. Hyland ME, Whalley B, Jones RC, Masoli M. A qualitative study of the impact of severe asthma and its treatment showing that treatment burden is neglected in existing asthma assessment scales. Qual Life Res. September 9, 2014. [Epub ahead of print.]

8. Summary of Product Characteristics. Spiriva Respimat 2.5 micrograms solution for inhalation. Electronic Medicines Compendium. Available from: http://www.medicines.org.uk/emc/medicine/20134. Accessed October 13, 2014.

9. Fardon T, Haggart K, Lee DK, Lipworth BJ. A proof of concept study to evaluate stepping down the dose of fluticasone in combination with salmeterol and tiotropium in severe persistent asthma. Respir Med. 2007;101:1218-1228.

10. Bateman ED, Kornmann O, Schmidt P, Pivovarova A, Engel M, Fabbri LM. Tiotropium is noninferior to salmeterol in maintaining improved lung function in B16-Arg/Arg patients with asthma. JAllergy Clin Immunol. 2011;128:315-322.

11. Beeh KM, Moroni-Zentgraf $\mathrm{P}$, Ablinger O, et al. Tiotropium Respimat ${ }^{\circledR}$ in asthma: a double-blind, randomised, dose-ranging study in adult asthma patients with moderate asthma. Respir Res. 2014;15:61.

12. Vogelberg C, Engel M, Moroni-Zentgraf P, et al. Tiotropium in asthmatic adolescents symptomatic despite inhaled corticosteroids: a randomised dose-ranging study. Respir Med. 2014;108:1268-1276.

13. Peters SP, Kunselman SJ, Icitovic N, et al. Tiotropium bromide step-up therapy for adults with uncontrolled asthma. $N$ Engl $J$ Med. 2010;363:1715-1726.

14. Roche N, Reddel HK, Agusti A, et al. Integrating real-life studies in the global therapeutic research framework. Lancet Respir Med. 2013;1:e29-e30.

15. Summary of Product Characteristics. Spiriva 18 microgram inhalation powder. Electronic Medicines Compendium. Available from: http:// www.medicines.org.uk/emc/medicine/10039. Accessed October 13, 2014.

16. Hohlfeld JM, Sharma A, van Noord JA, et al. Pharmacokinetics and pharmacodynamics of tiotropium solution and tiotropium powder in chronic obstructive pulmonary disease. J Clin Pharmacol. 2014;54: 405-414.

17. Mathioudakis AG, Chatzimavridou-Grigoriadou V, Evangelopoulou E, Mathioudakis GA, Siafakas NM. Comparative mortality risk of tiotropium administered via Handihaler or Respimat in COPD patients: are they equivalent? Pulm Pharmacol Ther. 2014;28:91-97.

18. Reddel HK, Taylor DR, Bateman ED, et al. An official American Thoracic Society/European Respiratory Society statement: asthma control and exacerbations. Am J Respir Crit Care Med. 2009;180: 59-59.

19. British Thoracic Society. SIGN 141. British guideline on the management of asthma. London, UK: 2014. Available from: https://www. brit-thoracic.org.uk/document-library/clinical-information/asthma/ btssign-asthma-guideline-2014/. Accessed October 13, 2014.

20. Sims EJ, Price D, Haughney J, Ryan D, Thomas M. Current control and future risk in asthma management. Allergy Asthma Immunol Res. $2011 ; 3: 217-225$. 


\section{Supplementary materials}

Table SI Baseline variables examined

\begin{tabular}{|c|c|}
\hline Variable & Description \\
\hline \multicolumn{2}{|c|}{ Variables examined at, or closest to, the index prescription date: ${ }^{a}$} \\
\hline Age & In years; also categorized as $18-40,4 I-60$, or $>60$ years \\
\hline Gender & Male or female \\
\hline Body mass index & In $\mathrm{kg} / \mathrm{m}^{2}$; categorized as underweight $(<18.5)$, normal $(18.5-24.9)$, overweight $(25-29.9)$, or obese $(\geq 30)$ \\
\hline Smoking status & Nonsmoker, current smoker, ex-smoker, or unknown \\
\hline $\mathrm{PEF}, \%$ predicted & $\begin{array}{l}\text { Predicted normal PEF }(\mathrm{L} / \mathrm{sec}) \text { was calculated as follows: for men, }(5.3 \mathrm{I} 7 \times \text { height }[\mathrm{m}])-(0.062 \times \text { age }[\mathrm{years}])+3.884 \text {; for } \\
\text { women, }(4.087 \times \text { height }[\mathrm{m}])-(0.05 \times \text { age }[\text { years] })+2.945 \text {; the patient's PEF reading was compared with the predicted } \\
\text { value and expressed as a percentage of predicted normal }\end{array}$ \\
\hline $\mathrm{FEV}_{1}, \%$ predicted & $\begin{array}{l}\text { Predicted normal } \mathrm{FEV}_{1}(\mathrm{~L}) \text { was calculated as follows: for men, }(4.3 \times \text { height }[\mathrm{m}])-(0.029 \times \text { age }[\text { years] })-2.49 \text {; for women, } \\
(3.95 \times \text { height }[\mathrm{m}])-(0.025 \times \text { age }[\text { years] })-2.6 \text {; for both, } 25 \text { years was used for age in patients } 18-25 \text { years; the patient's } \\
\text { FEV , reading was compared with the predicted value and expressed as a percentage of predicted normal }\end{array}$ \\
\hline FVC & Used to calculate $\mathrm{FEV} / \mathrm{FVC}$ ratio; also categorized as $<0.5,0.5-0.69$, or $\geq 0.7$ \\
\hline \multicolumn{2}{|c|}{ Variables examined regardless of when they occurred relative to index prescription date: ${ }^{\mathrm{a}}$} \\
\hline First asthma diagnosis & Date when asthma first diagnosed (if known) \\
\hline Comorbidities & $\begin{array}{l}\text { Including rhinitis (or prescription for rhinitis nasal spray), gastroesophageal reflux disease, and cardiac disease } \\
\text { (or prescription for cardiac drugs) }\end{array}$ \\
\hline $\begin{array}{l}\text { Charlson comorbidity } \\
\text { index score }\end{array}$ & Categorized as $0,1-4$, or $5+$ \\
\hline \multicolumn{2}{|c|}{ Variables examined in the year before the index prescription date: ${ }^{a}$} \\
\hline $\begin{array}{l}\text { Respiratory } \\
\text { treatments }\end{array}$ & All asthma, allergy, and other respiratory treatments \\
\hline ICS usage & $\begin{array}{l}\text { Where ICS prescribed, number of inhalers, dosage, and average daily dosage (averaged over the year); all ICS dosages } \\
\text { are in FP equivalents: large-particle BDP and budesonide dosages were divided by } 2 \text { to yield the FP-equivalent dosage; } \\
\text { extra-fine particle BDP and ciclesonide dosages were considered directly equivalent to FP dosages for this study }\end{array}$ \\
\hline $\begin{array}{l}\text { General practice } \\
\text { consultations }\end{array}$ & Number of general practice consultations, total and asthma-related \\
\hline Acute OCS courses & Number of acute OCS courses accompanied by lower respiratory consultation; ${ }^{c}$ total and categorized as $0,1,2$, or $3+$ \\
\hline BTS step & $\begin{array}{l}\text { Treatment step }(I-5) \text {, as described by BTS guidelines; }{ }^{\text {d step } 0} \text { was added to denote patients prescribed no asthma } \\
\text { treatment }\end{array}$ \\
\hline Hospitalization & Number of asthma-related A\&E attendances, inpatient admissions, or outpatient visits \\
\hline SABA usage & $\begin{array}{l}\text { Prescribed SABA dosage, averaged over the year: ([number of inhalers } \times \text { doses per inhaler] } \div 365) \times \text { strength }(\mu \mathrm{g}) \text {; all } \\
\text { SABA dosages are in salbutamol (albuterol) equivalents: terbutaline dosages were divided by } 2.5 \text { to yield the salbutamol- } \\
\text { equivalent dosage; average daily dosage and categorized as } 0,1-200,201-400 \text {, or }>400 \mu g / \text { day }\end{array}$ \\
\hline $\begin{array}{l}\text { Risk domain } \\
\text { of asthma control }\end{array}$ & A composite proxy measure of exacerbation risk (see text); controlled or uncontrolled \\
\hline $\begin{array}{l}\text { Antibiotic } \\
\text { prescriptions }\end{array}$ & Number of antibiotic prescriptions accompanied by lower respiratory consultation; total and categorized as $0, \mathrm{I}, 2$, or $3+$ \\
\hline Other medications & Prescription for $\beta$-blockers, NSAIDs, paracetamol (acetaminophen), tricyclic antidepressants, and statins \\
\hline Exacerbations & Number of asthma exacerbations (see text); total and categorized as $0,1,2$, or $3+$ \\
\hline $\begin{array}{l}\text { Acute respiratory } \\
\text { events }\end{array}$ & Number of acute events (see text); total and categorized as $0,1,2$, or $3+$ \\
\hline $\begin{array}{l}\text { Adherence to } \\
\text { ICS therapy }\end{array}$ & $\begin{array}{l}\text { Adherence }(\%)=(\text { total pack days } \div 365) \times 100 ; \text { where total pack days }=\text { sum }(\text { number of days/pack), and days/pack }= \\
\text { actuations/pack } \div \text { actuations/day }\end{array}$ \\
\hline $\begin{array}{l}\text { Controller-reliever } \\
\text { ratio }\end{array}$ & $\begin{array}{l}\text { Calculated as units of controllers } \div \text { (units of controllers }+ \text { units of relievers); controllers included ICS and LTRA, } \\
\text { one unit = one inhaler for ICS or one prescription for LTRA; relievers were limited to SABA, one unit = one inhaler; } \\
\text { LABA were excluded from this analysis, as ICS-LABA combination inhalers would have skewed the results }\end{array}$ \\
\hline
\end{tabular}

Notes: aDate of the patient's first tiotropium prescription; 'Aylin P, Bottle A, Jen MH, et al. HSMR mortality indicators. London, UK: Doctor Foster Research; 20I0. Available from: http://www.nhs.uk/scorecard/Documents/HSMR\%20methodology\%2009\%20November.pdf. Accessed on March 15, 20I3; cany lower respiratory consultation (asthma,

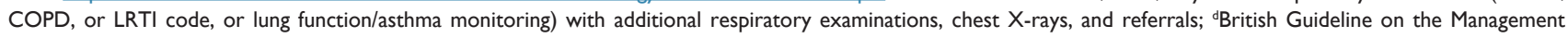
of Asthma. London, UK: British Thoracic Society; 2014. Available from: https://www.brit-thoracic.org.uk/document-library/clinical-information/asthma/btssign-asthmaguideline-2014/.

Abbreviations: A\&E, Accident and Emergency Department; BDP, beclomethasone dipropionate; BTS, British Thoracic Society; COPD, chronic obstructive pulmonary disease; FEV , forced expiratory volume in one second; FP, fluticasone propionate; FVC, forced vital capacity; ICS, inhaled corticosteroid; LABA, long-acting $\beta_{2}$ agonist; LTRA, leukotriene receptor antagonist; LRTI, lower respiratory tract infection; NSAIDs, nonsteroidal anti-inflammatory drugs; OCS, oral corticosteroid; PEF, peak expiratory flow; SABA, short-acting $\beta_{2}$ agonist. 
Table S2 Baseline patient characteristics: demographic and clinical variables

\begin{tabular}{|c|c|}
\hline \multicolumn{2}{|l|}{ Age (years) } \\
\hline Mean (SD) & $63.4(14.2)$ \\
\hline $18-40, \mathrm{n}(\%)$ & $136(6.7 \%)$ \\
\hline $41-60, n(\%)$ & 637 (3I.2\%) \\
\hline$>60, \mathrm{n}(\%)$ & $1,269(62.1 \%)$ \\
\hline \multicolumn{2}{|l|}{ Gender } \\
\hline Female, n (\%) & I,208 (59.2\%) \\
\hline BMI $\left(\mathrm{kg} / \mathrm{m}^{2}\right) ; \mathrm{n}(\%)$ & 1,959 (95.6\%) \\
\hline Mean (SD) & $29.2(6.7)$ \\
\hline Underweight (<18.5), n (\%) & $42(2.1 \%)$ \\
\hline Normal (I8.5-24.9), n (\%) & 488 (24.9\%) \\
\hline Overweight (25-29.9), n (\%) & $664(33.9 \%)$ \\
\hline Obese $(\geq 30), n(\%)$ & 765 (39.1\%) \\
\hline \multicolumn{2}{|l|}{ Smoking status, $n(\%)$} \\
\hline Nonsmoker & $849(41.6 \%)$ \\
\hline Current smoker & $322(15.8 \%)$ \\
\hline Ex-smoker & $682(33.4 \%)$ \\
\hline Unknown & $189(9.2 \%)$ \\
\hline PEF (\% predicted), n (\%) & I,358 (66.5\%) \\
\hline Mean (SD) & $69.3(21.8)$ \\
\hline $\mathrm{FEV}_{1}(\%$ predicted), n (\%) & $848(41.5 \%)$ \\
\hline Mean (SD) & $59.0(29.0)$ \\
\hline $\mathrm{FEV}_{1} / \mathrm{FVC}$ ratio, $\mathrm{n}(\%)$ & 780 (38.2\%) \\
\hline Mean (SD) & $0.6 \mathrm{I}(0.24)$ \\
\hline$<0.5, \mathrm{n}(\%)$ & $225(28.8 \%)$ \\
\hline $0.5-0.69, \mathrm{n}(\%)$ & $244(31.3 \%)$ \\
\hline$\geq 0.7, \mathrm{n}(\%)$ & $311(39.9 \%)$ \\
\hline \multicolumn{2}{|l|}{$\mathrm{CCl}$ score, n (\%) } \\
\hline 0 & 746 (36.5\%) \\
\hline $1-4$ & $854(41.8 \%)$ \\
\hline $5+$ & $442(21.6 \%)$ \\
\hline \multicolumn{2}{|l|}{ Comorbidities, n (\%) } \\
\hline Rhinitis $^{\mathrm{a}}$ & $730(35.7 \%)$ \\
\hline GERD & $301(14.7 \%)$ \\
\hline Cardiac disease $\mathrm{b}^{\mathrm{b}}$ & $1,286(63.0 \%)$ \\
\hline Ischemic heart disease & $308(15.1 \%)$ \\
\hline \multicolumn{2}{|l|}{ Comedications prescribed, n (\%) } \\
\hline$\beta$ blocker & $127(6.2 \%)$ \\
\hline NSAID & $820(40.2 \%)$ \\
\hline Paracetamol & 906 (44.4\%) \\
\hline Tricyclic antidepressant & $221(10.8 \%)$ \\
\hline Statin & $618(30.3 \%)$ \\
\hline
\end{tabular}

Notes: $n=2,042$, unless otherwise noted; adiagnosis at any time or nasal spray prescribed during baseline or outcome year; 'bdiagnosis or cardiac drugs prescribed at any time.

Abbreviations: $\mathrm{BMI}$, body mass index; $\mathrm{CCl}$, Charlson Comorbidity Index; FEV, forced expiratory volume in one second, expressed as percentage of predicted normal; FVC, forced vital capacity; GERD, gastroesophageal reflux disease; NSAID, nonsteroidal anti-inflammatory drug; PEF, peak expiratory flow, expressed as percentage of predicted normal; SD, standard deviation.
Table S3 Baseline smoking status by age group

\begin{tabular}{lllll}
\hline Age group & \multicolumn{2}{l}{ Smoking status } & \\
\cline { 2 - 5 } & Nonsmoker & $\begin{array}{l}\text { Current } \\
\text { smoker }\end{array}$ & $\begin{array}{l}\text { Ex- } \\
\text { smoker }\end{array}$ & Unknown \\
\hline $\begin{array}{l}\text { I8-40 years, } \\
\text { n (\%) }\end{array}$ & $58(6.8 \%)$ & $39(12.1 \%)$ & $26(3.8 \%)$ & $13(6.9 \%)$ \\
$\begin{array}{l}41-60 \text { years, } \\
\text { n (\%) }\end{array}$ & $228(26.9 \%)$ & $168(52.2 \%)$ & $186(27.3 \%)$ & $55(29.1 \%)$ \\
$\begin{array}{l}>60 \text { years, } \\
\text { n (\%) }\end{array}$ & $563(66.3 \%)$ & $115(35.7 \%)$ & $470(68.9 \%)$ & $121(64.0 \%)$ \\
$\begin{array}{l}\text { Total, n (\%) } \\
849(100 \%)\end{array}$ & $322(100 \%)$ & $682(100 \%)$ & $189(100 \%)$ \\
\hline
\end{tabular}

Table S4 Distribution of baseline $\mathrm{FEV}_{1} / \mathrm{FVC}$ ratio in patients over 60 years of age, by smoking status

\begin{tabular}{llll}
\hline FEV IFVC ratio & All & Current smokers & Ex-smokers \\
\hline$<0.5, \mathrm{n}(\%)$ & $156(29.1 \%)$ & $16(32.7 \%)$ & $74(33.9 \%)$ \\
$0.5-0.69, \mathrm{n}(\%)$ & $176(32.8 \%)$ & $19(38.8 \%)$ & $64(29.4 \%)$ \\
$\geq 0.7, \mathrm{n}(\%)$ & $204(38.1 \%)$ & $14(28.6 \%)$ & $80(36.7 \%)$ \\
Total, $\mathrm{n}(\%)$ & $536(100 \%)$ & $49(100 \%)$ & $218(100 \%)$ \\
\hline
\end{tabular}

Abbreviations: $\mathrm{FEV}_{1}$, forced expiratory volume in one second, expressed as percentage of predicted normal; FVC, forced vital capacity. 
Table S5 Baseline patient characteristics: asthma treatment and control

\section{SABA inhalers, $n$}

Median (IQR)

Primary care consultations, $\mathrm{n}$

Median (IQR)

Asthma consultations, ${ }^{a} \mathrm{n}$

Median (IQR)

$0, \mathrm{n}(\%)$

$\mathrm{I}, \mathrm{n}(\%)$

$2, \mathrm{n}(\%)$

$3+, \mathrm{n}(\%)$

Specific asthma medications, $\mathrm{n}(\%)$

None

SABA only

SAAC only

SABA + SAAC

$\mathrm{LABA} \pm \mathrm{SABA} / \mathrm{SAAC}$

$I C S \pm S A B A / S A A C$

ICS + LABA \pm SABA/SAAC

LTRA $\pm S A B A / S A A C$

ICS + LTRA \pm SABA/SAAC

ICS + LABA + LTRA \pm SABA/SAAC

LABA + LTRA + theophylline \pm SABA/SAAC

Theophylline

ICS inhalers, $\mathrm{n}$

Median (IQR)

Baseline ICS dosage $(\mu g / \text { day })^{\mathrm{b}, \mathrm{c}}$

Median (IQR)

$0, \mathrm{n}(\%)$

$\mathrm{I}-100, \mathrm{n}(\%)$

I0I-200, n (\%)

$20 \mathrm{I}-400, \mathrm{n}(\%)$

$40 \mathrm{I}-800, \mathrm{n}(\%)$

$>800, \mathrm{n}(\%)$

ICS dosage pre-IPD $(\mu g /$ day $),{ }^{c, d} \mathrm{n}(\%)$

Median (IQR)

ICS dosage at IPD $\left(\mu \mathrm{g} /\right.$ day), ${ }^{\mathrm{c}} \mathrm{n}(\%)$

Median (IQR)

Adherence to ICS (\%), n (\%)

Median (IQR)

$<50 \%$, n (\%)

$50 \%-69.9 \%, n(\%)$

70\%-99.9\%, n (\%)

$\geq 100 \%, n(\%)$

Controller-reliever ratio, $\mathrm{n}(\%)$

Median (IQR)

$<0.5, \mathrm{n}(\%)$

$\geq 0.5, \mathrm{n}(\%)$

LABA prescribed, $\mathrm{n}(\%)$

Spacer device used, $\mathrm{n}(\%)$

BTS step, n (\%)

0

I

2

3

4

5
$5(2,10)$

$14(9,22)$

I $(0,2)$

664 (32.5\%)

593 (29.0\%)

347 (17.0\%)

438 (21.4\%)

I 17 (5.7\%)

I 49 (7.3\%)

I I (0.5\%)

35 (1.7\%)

21 (1.0\%)

301 (14.7\%)

I,055 (51.7\%)

$16(0.8 \%)$

27 (I.3\%)

307 (15.0\%)

2 (0.1\%)

I $(<0.1 \%)$

$6(2,10)$

$247(66,493)$

352 (17.2\%)

296 (14.5\%)

3 II (15.2\%)

385 (18.9\%)

$436(21.4 \%)$

262 (12.8\%)

I,690 (82.8\%)

$500(200,1,000)$

537 (26.3\%)

$500(400,1,000)$

I,690 (82.8\%)

$100(73,134)$

201 (1 $1.9 \%)$

185 (10.9\%)

$45 \mathrm{I}(26.7 \%)$

$853(50.5 \%)$

I,909 (93.5\%)

$0.5(0.3,0.7)$

787 (4I.2\%)

I, I 22 (58.8\%)

I,385 (67.8\%)

279 (13.7\%)

I 18 (5.8\%)

$212(10.4 \%)$

252 (12.3\%)

439 (21.5\%)

I,0 I I (49.5\%)

$10(0.5 \%)$
Table S5 (Continued)

\begin{tabular}{ll}
\hline Hospitalization, $\geq \mathrm{I}^{\mathrm{e}} ; \mathrm{n}(\%)$ & \\
A\&E & $25(\mathrm{I} .2 \%)$ \\
Inpatient & $22(\mathrm{I} . \mathrm{I} \%)$ \\
Outpatient & $22(\mathrm{I} .1 \%)$
\end{tabular}

Notes: $n=2,042$, unless otherwise noted; anonspecialist primary care consultations where asthma was recorded; brescribed ICS dosage, averaged over the baseline year; in fluticasone-propionate equivalents; dosage prescribed at most recent consultation before IPD; eat least one asthma-related hospital visit during baseline year (categorized).

Abbreviations: A\&E, Accident and Emergency Department; BTS, British Thoracic Society; ICS, inhaled corticosteroid; IPD, index prescription date (date of first tiotropium script); IQR, interquartile range; LABA, long-acting $\beta_{2}$ agonist; LTRA, leukotriene receptor antagonist; SAAC, short-acting anticholinergic; SABA, shortacting $\beta_{2}$ agonist.

(Continued) 
Table S6 Comparison of effectiveness measures before (baseline) and after (outcome) addition of tiotropium

\begin{tabular}{|c|c|c|c|}
\hline Variable & Baseline & Outcome & $P$-value \\
\hline Exacerbations & & & $<0.00 I^{\mathrm{a}}$ \\
\hline Median (IQR) & $0(0,1)$ & $0(0,1)$ & \\
\hline $0, \mathrm{n}(\%)$ & $1,290(63.2 \%)$ & I,499 (73.4\%) & $<0.00 \mathrm{I}^{\mathrm{b}}$ \\
\hline $\mathrm{I}, \mathrm{n}(\%)$ & $415(20.3 \%)$ & $330(16.2 \%)$ & \\
\hline $2, \mathrm{n}(\%)$ & $180(8.8 \%)$ & $116(5.7 \%)$ & \\
\hline $3+, \mathrm{n}(\%)$ & 157 (7.7\%) & 97 (4.8\%) & \\
\hline Acute respiratory events & & & $<0.00 \mathrm{I}^{\mathrm{a}}$ \\
\hline Median (IQR) & I $(0,2)$ & $0(0,1)$ & \\
\hline $0, \mathrm{n}(\%)$ & $851(41.7 \%)$ & I,077 (52.7\%) & $<0.00 \mathrm{I}^{\mathrm{b}}$ \\
\hline I, n (\%) & $498(24.4 \%)$ & $506(24.8 \%)$ & \\
\hline $2, \mathrm{n}(\%)$ & $328(16.1 \%)$ & $218(10.7 \%)$ & \\
\hline $3+, \mathrm{n}(\%)$ & $365(17.9 \%)$ & $24 I(11.8 \%)$ & \\
\hline \multicolumn{4}{|l|}{$\begin{array}{l}\text { Risk domain of asthma } \\
\text { control }\end{array}$} \\
\hline Controlled, n (\%) & $846(41.4 \%)$ & I,07I (52.4\%) & $<0.00 \mathrm{I}^{\mathrm{c}}$ \\
\hline Acute OCS courses & & & $<0.00 \mathrm{I}^{\mathrm{a}}$ \\
\hline Median (IQR) & $0(0,1)$ & $0(0,1)$ & \\
\hline $0, n(\%)$ & $1,310(64.2 \%)$ & I,52। (74.5\%) & $<0.00 \mathrm{I}^{\mathrm{b}}$ \\
\hline I, n (\%) & $402(19.7 \%)$ & $316(15.5 \%)$ & \\
\hline $2, \mathrm{n}(\%)$ & 175 (8.6\%) & II 5 (5.6\%) & \\
\hline $3+, \mathrm{n}(\%)$ & 155 (7.6\%) & 90 (4.4\%) & \\
\hline Antibiotic prescriptions & & & $<0.00 \mathrm{I}^{\mathrm{a}}$ \\
\hline Median (IQR) & I $(0,2)$ & $0(0,1)$ & \\
\hline $0, \mathrm{n}(\%)$ & 999 (48.9\%) & I,200 (58.8\%) & $<0.00 \mathrm{I}^{\mathrm{b}}$ \\
\hline I, n (\%) & 469 (23.0\%) & 440 (21.5\%) & \\
\hline $2, \mathrm{n}(\%)$ & $268(13.1 \%)$ & $196(9.6 \%)$ & \\
\hline $3+, \mathrm{n}(\%)$ & $306(15.0 \%)$ & $206(10.1 \%)$ & \\
\hline PEF (\% predicted), n (\%) & 926 (45.3\%) & $926(45.3 \%)$ & \\
\hline Mean (SD) & $70.0(21.5)$ & $69.5(21.7)$ & $0.37 I^{d}$ \\
\hline $\mathrm{FEV}_{1}$ (\% predicted), n (\%) & $398(19.5 \%)$ & $398(19.5 \%)$ & \\
\hline Mean (SD) & $58.0(29.5)$ & $57.9(30.5)$ & $0.935^{d}$ \\
\hline $\mathrm{FEV}_{1} / \mathrm{FVC}$ ratio, n (\%) & $353(17.3 \%)$ & $353(17.3 \%)$ & \\
\hline$<0.5$ & 91 (25.8\%) & $116(32.9 \%)$ & $0.382^{\mathrm{b}}$ \\
\hline $0.5-0.69$ & $122(34.6 \%)$ & $86(24.4 \%)$ & \\
\hline$\geq 0.7$ & 140 (39.7\%) & $15 \mid(42.8 \%)$ & \\
\hline SABA usage $(\mu \mathrm{g} / \text { day })^{\mathrm{e}}$ & & & $0.010^{\mathrm{a}}$ \\
\hline Median (IQR) & $274(110,548)$ & $329(110,603)$ & \\
\hline $0, n(\%)$ & $327(16.0 \%)$ & $317(15.5 \%)$ & $0.006^{\mathrm{b}}$ \\
\hline $\mathrm{I}-200, \mathrm{n}(\%)$ & $493(24.1 \%)$ & $450(22.0 \%)$ & \\
\hline $20 \mathrm{I}-400, \mathrm{n}(\%)$ & $45 \mathrm{I}(22.1 \%)$ & $45 I(22.1 \%)$ & \\
\hline$>400, \mathrm{n}(\%)$ & 77 ( $(37.8 \%)$ & $824(40.4 \%)$ & \\
\hline
\end{tabular}

Notes: $n=2,042$, unless otherwise noted; aWilcoxon signed-rank test; ${ }^{b}$ marginal homogeneity test; 'McNemar test; 'paired $t$-test; 'in salbutamol (albuterol) equivalents. Abbreviations: $\mathrm{FEV}_{1}$, forced expiratory volume in one second, expressed as percentage of predicted normal; FVC, forced vital capacity; IQR, interquartile range; OCS, oral corticosteroid; PEF, peak expiratory flow, expressed as percentage of predicted normal; SABA, short-acting $\beta_{2}$ agonist; SD, standard deviation.
Table S7 Sensitivity analysis: comparison of primary measures before (baseline) and after (outcome) addition of tiotropium

\begin{tabular}{|c|c|c|c|}
\hline Variable & Baseline & Outcome & $P$-value \\
\hline Exacerbations & & & $<0.00 \mathrm{I}^{\mathrm{a}}$ \\
\hline Median (IQR) & $0(0,1)$ & $0(0,1)$ & \\
\hline $0, \mathrm{n}(\%)$ & $565(60.9 \%)$ & $654(70.5 \%)$ & $<0.00 I^{b}$ \\
\hline $\mathrm{I}, \mathrm{n}(\%)$ & $198(21.3 \%)$ & $167(18.0 \%)$ & \\
\hline $2, \mathrm{n}(\%)$ & $93(10.0 \%)$ & $62(6.7 \%)$ & \\
\hline $3+, \mathrm{n}(\%)$ & $72(7.8 \%)$ & $45(4.8 \%)$ & \\
\hline Acute respiratory events & & & $<0.00 I^{\mathrm{a}}$ \\
\hline Median (IQR) & I $(0,2)$ & $0(0,1)$ & \\
\hline $0, \mathrm{n}(\%)$ & 361 (38.9\%) & $476(51.3 \%)$ & $<0.00 \mathrm{I}^{\mathrm{b}}$ \\
\hline $\mathrm{I}, \mathrm{n}(\%)$ & 231 (24.9\%) & $228(24.6 \%)$ & \\
\hline $2, \mathrm{n}(\%)$ & $149(16.1 \%)$ & $108(11.6 \%)$ & \\
\hline $3+, n(\%)$ & $187(20.2 \%)$ & $116(12.5 \%)$ & \\
\hline
\end{tabular}

Notes: $n=928$; ${ }^{a}$ Wilcoxon signed-rank test; ${ }^{b}$ marginal homogeneity test.

Abbreviation: IQR, interquartile range.

\section{References}

1. Aylin P, Bottle A, Jen MH, Middleton S. HSMR mortality indicators. London; UK. Doctor Foster Research; 2010. Available from: http:// www.nhs.uk/scorecard/Documents/HSMR\%20methodology\%2009\%20 November.pdf. Accessed March 15, 2014.

2. British Guideline on the Management of Asthma. London; UK. British Thoracic Society; 2014. Available from: https://www.brit-thoracic. org.uk/document-library/clinical-information/asthma/btssign-asthmaguideline-2014/. Accessed October 13, 2014
Journal of Asthma and Allergy

\section{Publish your work in this journal}

The Journal of Asthma and Allergy is an international, peer-reviewed open-access journal publishing original research, reports, editorials and commentaries on the following topics: Asthma; Pulmonary physiology; Asthma related clinical health; Clinical immunology and the immunological basis of disease; Pharmacological interventions and

\section{Dovepress}

new therapies. Issues of patient safety and quality of care will also be considered. The manuscript management system is completely online and includes a very quick and fair peer-review system, which is all easy to use. Visit http://www.dovepress.com/testimonials.php to read real quotes from published authors. 